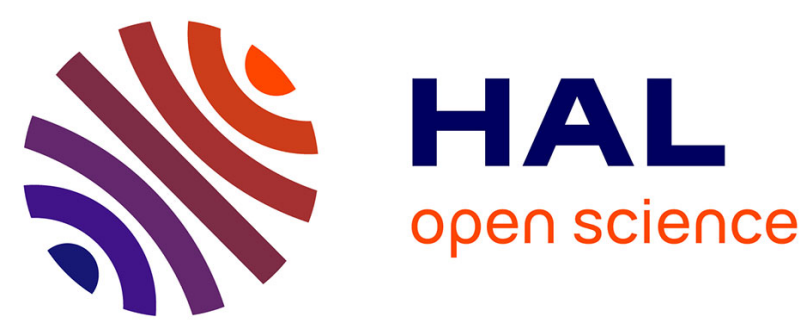

\title{
Spatial distribution and corresponding determining factors of metal concentrations in surface sediments of Beppu Bay, southwest Japan
}

\author{
Atsuko Amano, Michinobu Kuwae, Tetsuro Agusa, Koji Omori, Hidetaka
} Takeoka, Shinsuke Tanabe, Takashige Sugimoto

\section{To cite this version:}

Atsuko Amano, Michinobu Kuwae, Tetsuro Agusa, Koji Omori, Hidetaka Takeoka, et al.. Spatial distribution and corresponding determining factors of metal concentrations in surface sediments of Beppu Bay, southwest Japan. Marine Environmental Research, 2011, 71 (4), pp.247. 10.1016/j.marenvres.2011.01.009 . hal-00682415

\section{HAL Id: hal-00682415 https://hal.science/hal-00682415}

Submitted on 26 Mar 2012

HAL is a multi-disciplinary open access archive for the deposit and dissemination of scientific research documents, whether they are published or not. The documents may come from teaching and research institutions in France or abroad, or from public or private research centers.
L'archive ouverte pluridisciplinaire HAL, est destinée au dépôt et à la diffusion de documents scientifiques de niveau recherche, publiés ou non, émanant des établissements d'enseignement et de recherche français ou étrangers, des laboratoires publics ou privés. 


\section{Accepted Manuscript}

Title: Spatial distribution and corresponding determining factors of metal concentrations in surface sediments of Beppu Bay, southwest Japan

Authors: Atsuko Amano, Michinobu Kuwae, Tetsuro Agusa, Koji Omori, Hidetaka Takeoka, Shinsuke Tanabe, Takashige Sugimoto

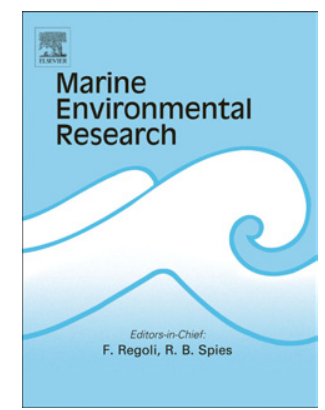

PII:

S0141-1136(11)00020-1

DOI:

10.1016/j.marenvres.2011.01.009

Reference: MERE 3505

To appear in: Marine Environmental Research

Received Date: 4 December 2009

Revised Date: 14 May 2010

Accepted Date: 27 January 2011

Please cite this article as: Amano, A., Kuwae, M., Agusa, T., Omori, K., Takeoka, H., Tanabe, S., Sugimoto, T. Spatial distribution and corresponding determining factors of metal concentrations in surface sediments of Beppu Bay, southwest Japan, Marine Environmental Research (2011), doi: 10.1016/j.marenvres.2011.01.009

This is a PDF file of an unedited manuscript that has been accepted for publication. As a service to our customers we are providing this early version of the manuscript. The manuscript will undergo copyediting, typesetting, and review of the resulting proof before it is published in its final form. Please note that during the production process errors may be discovered which could affect the content, and all legal disclaimers that apply to the journal pertain. 
sediments of Beppu Bay, southwest Japan

Atsuko Amano ${ }^{1}$, Michinobu Kuwae ${ }^{2}$, Tetsuro Agusa ${ }^{3}$, Koji Omori $^{4}$, Hidetaka Takeoka ${ }^{4}$, Shinsuke Tanabe ${ }^{4}$, Takashige Sugimoto ${ }^{5}$

${ }^{1}$ : Geological Survey of Japan, National Institute of Advanced Industrial Science and Technology, 1-1-1 Higashi, Tsukuba 305-8567, Japan

2: Senior Research Fellow Center, Ehime University, Bunkyo-cho 2-5, Matsuyama 790-8577, Japan

3: Department of Legal Medicine, Faculty of Medicine, Shimane University, Shioji 89-1, Izumo, Shimane 693-8501, Japan

4: Center for Marine Environmental Studies, Ehime University, Bunkyo-cho 2-5, Matsuyama 790-8577, Japan

5: Institute of Oceanic Research and Development, Tokai University, Shizuoka 424-8610, Japan

Corresponding author. Tel.: +8129861 3767; fax: +81298613747.

E-mail address: amano-a@aist.go.jp (A. Amano)

\section{Abstract}

This study determined the factors contributing to the spatial distribution of 14 metal concentrations in 
the surface sediments of Beppu Bay on the basis of comparisons of the organic geochemical properties and

environmental parameters through principal component analysis (PCA) and redundancy analysis (RDA). The results of PCA and RDA showed that the concentrations of $\mathrm{V}, \mathrm{Cr}, \mathrm{Co}$, and As were closely related to the distances between the sampling sites and the Oita River. This indicated that these metals originated from the river's drainage area. The $\mathrm{Mn}, \mathrm{Cu}, \mathrm{Mo}$, and $\mathrm{Cd}$ concentrations were related to the water depth. These results indicated that the $\mathrm{Mo}, \mathrm{Cd}$, and $\mathrm{Cu}$ deposition processes were controlled by oxygen depletion, and that these elements accumulated in the deeper parts of the bay under anoxic conditions.

Keywords: surface sediment; metal; organic geochemical property; redox condition; PCA; RDA

\section{Introduction}

Semi-enclosed coastal areas such as estuaries and bays are characterized by stagnant conditions and the

supply with water inflow from land. As a result, materials supplied from the watershed area accumulate in this type of coastal areas, which is likely to cause environmental pollution. In particular, recent human activities have had a strong impact on these semi-enclosed environments. In order to identify the causes of marine pollution, it is important to determine the sources and transfer processes of pollutants. However, the physical transport processes in a coastal area are very complicated because of drastic environmental changes to the border 
minerals, biogenic materials, and urban and industrial human activities, and they have complex deposition processes. Therefore, it is often difficult to determine the main factor driving the transfer and deposition processes for metals in sediments. In an effort to understand the supply sources and deposition processes of metals in semi-enclosed areas, many studies have attempted to determine the spatial distribution of metal concentrations in surface sediments and explain the controlling factors through simple correlations and principal component analysis (PCA) (e.g., Ergin et al., 1991; Rubio et al., 2002; Cassia et al., 2003; Reid and Spencer, 2009). These studies elucidated the relationships between metal concentrations and other sedimentary parameters, such as grain size, organic/inorganic matter properties, and metals, and discussed the sources and diffusion processes of the metals in sediments. In order to indicate the sources in a drainage area and their relationships with the chemical behavior of seawater, it is essential to correlate the metal concentrations, environmental properties, such as bathymetric and topographic parameters and measurement data. Therefore, we determined the spatial variations and corresponding controlling factors of metal concentrations in the sediments of Beppu Bay and correlated them with environmental parameters using statistical analyses.

Beppu Bay is located on the western part of the Seto Inland Sea in southwest Japan (Fig. 1). It is characterized by a shallow bay mouth with a water depth that increases toward the interior of the bay; as a result, it is hydrodynamically stagnant. These features form a strong thermocline and low to zero oxygen concentration at the bottom during the summer to autumn seasons (Shiozawa et al., 1977). Several rivers flow 
tourism. Kuwae et al. (2007) focused on the sediments of Beppu Bay and reported a wide variation in redox conditions in an effort to understand the oxygen depletion process in semi-enclosed bays. In addition, they explained the relationships between the spatial variations in the organic geochemical properties of sediments and environmental variables, which are mainly due to the supply from the rivers and the redox conditions.

This study focused on 14 metals that are sensitive to the redox conditions, geology, and anthropogenic impacts of the watershed area; we investigated the spatial distributions of the concentrations of surface sediments in Beppu Bay. To determine the controlling factors for variations in metal concentrations, we used PCA, RDA, and simple correlation to investigate the relationships between the geochemical properties, measured bottom condition data, and bathymetric parameters.

\section{Study area}

Beppu Bay is located on the western part of the Seto Inland Sea in southwest Japan (Fig. 1). Its basin has a maximum depth of $72 \mathrm{~m}$ in the interior with a sill of $53 \mathrm{~m}$ depth at the bay mouth. These bathymetric features have caused the bottom conditions to become strongly stagnant. The tidal current velocity near the bottom is so low that it is undetectable, even using a current meter with a detection limit of $2 \mathrm{~cm} / \mathrm{s}$ (Hoshika et al., 1978). The surface sediments in the interior of the bay were found to mainly contain silty clay, whereas 
those from the area outside the sill mainly contained fine sand sediments (Inouchi, 1990). This hydrodynamic

condition is associated with a thermocline that has strong temperature and salinity gradients that form at a water depth of $60 \mathrm{~m}$ in the basin from July to November (Shiozawa et al., 1977). Accompanying this process, the dissolved oxygen (DO) of the bottom water varies seasonally. The $\mathrm{DO}$ is $6 \mathrm{ml} / \mathrm{L}$ from January to March and decreases to almost zero by September; further, hydrogen sulfide has been observed between August and November (Shiozawa et al., 1977; Hoshika et al., 1988; Kameda and Fujiwara, 1995).

The main rivers flowing into the bay are the Oita and Ono rivers. They flow into the southern area of the bay, and have drainage areas of 650 and $1465 \mathrm{~km}^{2}$, respectively. These areas account for approximately $70 \%$ of the Beppu Bay watershed. Multiple industrial zones containing steel plants and petrochemical complexes are located in the southern coastal area around the mouths of the Oita and Ono rivers, and electronics plants exist in the watershed area of the Ono River. Beppu City, which is located on the western part of the bay, has numerous hot springs.

\section{Materials and Methods}

\subsection{Sampling and analysis}

Surface sediments (the uppermost $1 \mathrm{~cm}$ ) were collected in August 2006 from Beppu Bay at 16 sites 
using a Smith-McIntyer grab sampler (Fig. 1; Table 1).A Mostly clay-silt grains were observed in all of the

samples. At the same time, undisturbed samples collected by a gravity corer were used to measure the temperature and dissolved oxygen (DO) concentrations of the bottom water and the redox potential (Eh) of the upper surface sediments were measured using a DO/Eh meter (D-55, HORIBA, Ltd., Japan).

Sediment samples were dried at $60^{\circ} \mathrm{C}$ for $24 \mathrm{~h}$ and ground to a fine powder. Approximately $0.2 \mathrm{~g}$ of a powdered sample was digested by a microwave system (Ethos D, Milestone S.r.1., Sorisole, BG, Italy) with an acid mixture $\left(\mathrm{HNO}_{3}: \mathrm{HF}=6: 1\right)$ in a Teflon vial. The digested sample was dried to remove all of the acid. The residue was dissolved with $\mathrm{HNO}_{3}$ and then diluted with Milli-Q water. The Al, V, Cr, Mn, Fe, Co, Cu, Zn, As, $\mathrm{Mo}, \mathrm{Ag}, \mathrm{Cd}$, In, and $\mathrm{Pb}$ concentrations were determined by inductively coupled plasma-mass spectrometers (ICP-MS; HP-4500, Hewlett-Packard, Avondale, PA, USA and 7500cx, Agilent, Palo Alto, CA, USA). The metal analysis was conducted in duplicate. The analytical quality was assessed using standard reference materials, NIES No. 2 pond sediments, and NIES No. 12 marine sediments (National Institute for Environmental Study, Tsukuba, Japan), and the recovery of metals was $80-110 \%$. In this study, metal concentrations were expressed as $\mu \mathrm{g} / \mathrm{g}$ dry wt.

\subsection{Data analysis}

In order to examine the relationships between the metals concentrations and other factors, we used 
ordination techniques. Numerous studies have primarily used two multivariate ordination techniques. One

of these consisted of the linear ordination methods such as principal components analysis (PCA) and redundancy analysis (RDA). These analyses were performed to determine the variation in the species data within a narrow range, which could be attributed to linear coupling. Another study used unimodal based methods of correspondence analysis (CA), detrended correspondence analysis (DCA), and canonical correspondence analysis (CCA) to determine the variation in the species data over a wide range. DCA was carried out on the metal data to determine the most appropriate method, with the gradient length as the criterion (ter Braak, 1988). The results of DCA showed that linear methods (PCA and RDA) were preferable for the dataset considered in this study; this was because the gradient length in standard deviation unites appeared to be not larger than two by the analysis (Birks, 1995). In order to identify the primary factors influencing the variations in the geochemical parameters, we performed PCA for two cases. One involved analysesthe 14 metal concentrations investigated in this study (Table 2). The other involved analyses of the metals and seven organic matter parameters measured by Kuwae et al. (2007) (Fig. 2; Table 1); these include stable isotope ratios of organic carbon $\left(\delta^{13} \mathrm{C}\right)$ and nitrogen $\left(\delta^{15} \mathrm{~N}\right)$; total organic carbon $(\mathrm{TOC})$, total nitrogen $(\mathrm{TN})$, and total sulfur (TS) content; and ratios of total organic carbon to total nitrogen $(\mathrm{C} / \mathrm{N})$ and sulfur $(\mathrm{C} / \mathrm{S})$. RDA and a simple correlation analysis were used to examine the relationships between the metal concentrations and the seven environmental variables: water depth; distances from the mouths of Oita, Ono, and Haruki rivers; temperature and DO of the bottom water; and Eh of the uppermost surface sediment, shown in Fig. 2 and Table 1. The 
Windows 4.5 (ter Braak and Smilauer, 2002). In the RDA computations, the correlation matrix option was selected, and scaling was conducted on a correlation biplot. The significance of each environmental variable was tested using 499 unrestricted Monte Carlo permutations.

\section{Results}

\subsection{Distribution pattern of metal concentrations}

The spatial distributions of the metal concentrations in the surface sediments of Beppu Bay were classified into four patterns (Fig. 2; Table 3). The concentrations of V, Cr, Co, As, and Ag were relatively high on the southern coast (Sites 1-5) and decreased toward the northern part of the bay. The concentration ranges were $62-95,34-76,7.7-15.6,7.2-22.3$, and $0.22-0.46 \mu \mathrm{g} / \mathrm{g}$, respectively. The distribution pattern for the Fe concentrations (27 800-39 $200 \mu \mathrm{g} / \mathrm{g}$ ) was similar to these metals, although the value for Site 10 in the northwest was higher than the average for the bay. The indium concentrations were relatively high at $>1.1 \mu \mathrm{g} / \mathrm{g}$ at the offshore parts of the Oita and Ono river mouths (Sites 1-3) and $<0.2 \mu \mathrm{g} / \mathrm{g}$ at the other sites. In contrast, the distribution patterns for the $\mathrm{Al}, \mathrm{Zn}$, and $\mathrm{Pb}$ concentrations showed relatively low values on the southern coast and increased toward the north and west. These metals had ranges of $44100-71800,111-144$, and 24.7-32.2 
toward the bay mouth from the southwest, which is where the deepest basin lies in the interior of the bay. In contrast, the distribution patterns for $\mathrm{Cu}, \mathrm{Mo}$, and $\mathrm{Cd}$ showed increases in the deeper parts from the bay mouth with ranges of $25.9-37.3,1.1-12.9$, and $0.19-0.47 \mu \mathrm{g} / \mathrm{g}$, respectively.

\subsection{Principal component analysis of geochemical parameters}

The PCA results for the metal concentrations revealed two main axes that explain most of the variations (Fig. 4; Table 3). The first principal component (PC1) accounted for $43 \%$ of the variation; when taken together with the second principal component (PC2), this value increased to $71 \%$ (Table 3). The loadings of $\mathrm{V}, \mathrm{Cr}, \mathrm{Co}, \mathrm{As}$, and $\mathrm{Pb}$ on $\mathrm{PC} 1$ were high $(0.98,0.90,0.95,0.97$, and -0.73 , respectively); however, the loadings of $\mathrm{Mn}, \mathrm{Cu}, \mathrm{Mo}, \mathrm{Cd}$, and In were low $(-0.08,0.09,-0.26,-0.06$, and 0.44 , respectively). In contrast, the loadings of $\mathrm{Mn}, \mathrm{Cu}, \mathrm{Mo}, \mathrm{Ag}$, and Cd on PC2 were high $(-0.73,0.79,0.83,0.70$, and 0.92, respectively), while the other parameters exhibited low values. Samples from Sites 3-5, which were located near the Oita River mouth on the southern coast of the bay, were characterized by high PC1 and low PC2 values. These samples showed the same trends in the PCA results as the V, As, Cr, Co, and In values. In contrast, samples from Sites 6-8, which were located in the deepest and innermost regions of the bay, were characterized by high PC2 values, and samples from Sites 10 and 13-16, which were located on the northern part of the bay, were characterized by 
for the $\mathrm{Mo}, \mathrm{Cd}$, and $\mathrm{Cu}$ values; on the other hand, samples from Sites 10 and 13-16, which were from shallower areas, showed the same trends for the Mn values.

The PCA results for the metals and organic matter parameters revealed two main axes that explained most of the variation (Fig. 5; Table 4). The first principal component (PC1) accounted for $50 \%$ of the variation; when taken together with the second principal component (PC2), this value increased to $77 \%$. The V, Cr, Co, Zn, As, $\delta^{13} \mathrm{C}, \delta^{15} \mathrm{~N}, \mathrm{C} / \mathrm{N}, \mathrm{TN}, \mathrm{TS}$, and C/S loadings on PC1 were high $(0.88,0.86,0.94,-0.78,0.88$, $-0.89,-0.92,0.94,-0.74,-0.92$, and 0.90 , respectively). In contrast, the $\mathrm{Mn}, \mathrm{Cu}, \mathrm{Mo}, \mathrm{Ag}, \mathrm{Cd}$, and TOC loadings on PC2 were high $(0.69,-0.76,-0.70,-0.88,-0.85$, and -0.81 , respectively), while the other parameters exhibited low values. Samples from Sites 3-5 were characterized by high PC1 and low PC2 values. These samples showed the same trends for the $\mathrm{V}, \mathrm{As}, \mathrm{Cr}, \mathrm{Co}, \mathrm{In}$, and $\mathrm{C} / \mathrm{N}$ values, which were the opposite to those for $\delta^{13} \mathrm{C}$, $\delta^{15} \mathrm{~N}$, and $\mathrm{Pb}$. In contrast, samples from Sites $6-8$ were characterized by low PC2 values, and those from Sites 10 and 13-16 were characterized by high PC2 values. The samples from Sites $6-8$ showed the same trends for the $\mathrm{Mo}, \mathrm{Cd}, \mathrm{Cu}$, and TOC values, while the samples from Sites 10 and 13-16 showed the same trends for the Mn values.

\subsection{Redundancy and simple correlation analysis of geochemical parameters and} environmental variables 
The eigenvalues of the first two RDA axes were high (RDA axis 1 (RD1): 0.35 and RDA axis 2 (RD2):

0.27) when compared with the subsequent axes and accounted for $61.8 \%$ of the variance in the geochemical data

(Fig. 6; Table 5). The correlations between the geochemical data and environmental variables for RD1 and RD2 were high ( 0.91 and 0.99 , respectively). Both of the axes together accounted for $82.6 \%$ of the variance in the relation between the metals and seven environment variables. The results of the permutation tests revealed that two environmental variables had statistically significant effects: the water depth $(P=0.002)$ and distance from the Oita River mouth $(P=0.002)$. On the other hand, the results revealed that the following had insignificant effects: the bottom temperature, Eh, DO, and distances from the Ono and Haruki river mouths. The distance from the Oita River mouth showed a significant correlation with RD1 $(r=-0.79)$ because the absolute t-value of the regression coefficient was greater than two (ter Braak and Smilauer, 2002) (Table 6). In addition, the depth showed a significant correlation with $\mathrm{RD} 2(r=0.90$, Table 6). The RDA results (Fig. 6) demonstrated a pattern similar to the PCA results (Fig. 4). The trends of the metals and samples along the RDA axes were also similar to those along the PCA axes. This implies that the distribution patterns for the variations in the metals, as revealed in the RDA axes, were reliable. The RDA results revealed two close relationships between the metal concentrations and environmental variables. One was the relationship between the $\mathrm{V}$, As, $\mathrm{Cr}$, $\mathrm{Co}, \mathrm{In}$, and $\mathrm{Pb}$ values and the distance from the Oita River mouth. The other was the relationship between the $\mathrm{Cu}, \mathrm{Cd}, \mathrm{Mo}$, and $\mathrm{Mn}$ values and the water depth. The trend of the distribution 
patterns for the sample scores associated with Sites $2-5$ was similar to the arrows in relation to the distance from

the Oita River mouth. Therefore, the sample score variations associated with Sites $2-5$ were mainly attributed to the variations in the distance from the river mouth. In contrast, the distribution patterns for the sample scores associated with Sites 6, 7, 10,14, and 16 were parallel to the arrow trends in relation to the water depth.

This indicates that these sample score variations can be mainly attributed to the variations in water depth.

The results of the simple correlation analysis showed trends similar to the RDA results (Table 7); however, there were some differences. The $\mathrm{V}, \mathrm{Cr}, \mathrm{Co}, \mathrm{As}$, and $\mathrm{Pb}$ concentrations were correlated with the distances from the Oita River, while In was correlated with the distances from both the Oita and Ono rivers. These results indicated that the controlling factors for the In concentrations in the sediments were closely related to both of these rivers.

\section{Discussion}

\subsection{Influences of supply from the drainage area}

The PCA results for metal concentrations demonstrated that the $\mathrm{V}, \mathrm{Co}, \mathrm{Cr}, \mathrm{As}$, and $\mathrm{Pb}$ concentrations were affected by common factors (Fig. 4; Table 3). The other PCA results for metals and organic geochemical parameters showed that these metal concentrations were closely related to $\mathrm{C} / \mathrm{N}, \delta^{13} \mathrm{C}$, and $\delta^{15} \mathrm{~N}$, which are 
surface sediments in Beppu Bay were closely related to the distance between the Oita River mouth and the sampling sites (Kuwae et al., 2007). By the same token, the RDA results suggested that the spatial variations for these metal concentrations were controlled by the distances from the sampling sites to the Oita River mouth (Fig. 6; Table 5).

The V, Cr, Co, and As concentrations were relatively high around the mouths of the Oita and Ono rivers on the southern coast (Fig. 3); according to the PCA and RDA results (Tables 4 and 6), they had positive relations with $\mathrm{C} / \mathrm{N}$ and their distances from the Oita River mouth and negative relations with $\delta^{13} \mathrm{C}$ and $\delta^{15} \mathrm{~N}$. These relationships indicate that these metals originated in the drainage area for the Oita River in the same manner as terrestrial organic matter. The $\mathrm{V}, \mathrm{Cr} \mathrm{Co}$, and As concentrations for the surface sediments in Beppu Bay ranged between several-fold greater and one-third of the global mean values for the crust (Bowen, 1979) and background values of the fluvial sediments in the Oita River (Imai et al., 2004) (Table 2). Previous studies have explained that the V, Cr, Co, and As sources are closely related to industry (e.g., Pekey et al., 2006; García et al., 2008); however, this is not very likely for Beppu Bay. Therefore, these metals likely originated from clastic fractions in the drainage area of the Oita River.

The RDA and simple correlation analysis results suggested that In was supplied from both the Oita and Ono rivers (Fig. 6; Table 7). The In concentration in Beppu Bay was very high, over twenty times the crustal value (Table 2); this result implies the influence of special accumulation processes. Previous studies have not 
understood for coastal estuarine systems. In is used industrially as indium tin oxide alloys for manufacturing flat panel displays and semiconductors for high technology (Roskill Information Services Ltd., 1996). The drainage areas for the Oita and Ono rivers have plants producing electronic devices and accurate instruments; therefore, these plants may be the In sources.

The lead concentrations in the surface sediments were low around the Oita River mouth (Fig. 3) and had trends that were opposite to those exhibited by the V, Cr, Co, As, and In concentrations in the PCA and RDA results (Figs. 4 and 6). These results suggest that the deposition processes for $\mathrm{Pb}$ were likely associated with marine plankton and/or supply from drainage areas of the bay excluding the Oita River. Many studies have described increases in $\mathrm{Pb}$ concentrations in coastal sediments as caused by particulates produced during the burning of coal and oil fuel (e.g., Gracía et al., 2008). Lead products exhausted from human activities in the surrounding bay area may have diffused through the atmosphere toward the sea, and the $\mathrm{Pb}$ concentrations in the surface sediments may have been diluted by clastic sediments supplied from the Oita and Ono rivers. Therefore, these statistical results may show the relationship between the $\mathrm{Pb}$ concentrations and the distance from the Oita River.

The RDA results showed that the $\mathrm{Al}, \mathrm{Fe}, \mathrm{Zn}$, and $\mathrm{Ag}$ concentrations were weakly correlated with the environmental parameters used in this study (Fig. 6). These results suggest that variations in these metal concentrations were controlled by other factors such as parameters not considered in this study and/or multiple 
factors. In order to explain the depositional processes of these metals, we considered the possibilities of relation

with other factors and sources.

In general, the metal concentrations of sediments vary with grain size (e.g., Imai et al., 1997; Lin et al., 2002; Neto et al., 2006; Ohta et al., 2007). Aluminum is a structural element of clay and its concentration is relatively constant in the crust (Schropp et al., 1990; Summers et al., 1996). Although the median diameters of the sediments in the Beppu Bay interior were over $6 \varphi$, the mud content (over $4 \varphi$ ) slightly decreased to $85 \%$ around the Oita and Ono river mouths from more than $90 \%$ in the main part of the bay (Inouchi, 1990). This pattern reflects the deposition process for coarser sediments from the Oita and Ono river drainage areas. To explain the variation in grain size, a trend of decreasing $\mathrm{Al}$ concentration may accompany a decrease in mud content.

The Fe concentrations showed middle negative values in RD1 and positive values in RD2 and negative relations with the distances from the Oita River mouth and the water depth (Fig. 6; Table 6). This result implies that the spatial distribution of Fe concentration in the surface sediments was influenced by the following two topographic parameters: supply from the Oita River, as with the V, Cr, Co, and As concentrations, and the redox conditions. Although we explain the relationships between the metal concentrations and redox conditions in the next section, Shiozawa et al. (1977) demonstrated that Fe dissolves from sediments in anoxic conditions during the summer season; they used vertical profiles of seawater from the deepest part of the bay for dissolved and particulate metals. However, no data are available that show the diffusion process in the horizontal direction after materials are dissolved from sediments. Although it is currently difficult to explain 
the relationship between the Fe concentrations and redox conditions, if a transfer process for dissolved $\mathrm{Fe}$ in

seawater can be demonstrated, the reason that the Fe concentrations in the surface sediments decrease toward the deeper part of the bay will be elucidated.

Zinc concentrations increased toward the western part of the bay (Fig. 3). RDA results indicated that the distance from the Ono River was an insignificant factor in the variation of the metal concentrations. However, the same trend was observed for Zn concentration and the distance from Ono River shown in Fig. 6. A geochemical map of Japan produced by Imai et al. (2004) demonstrated that the Zn concentrations in the western part of the bay, including Beppu City, were much higher than in the southern part, which is where the Ono River flows. Osawa et al. (2007) showed that the $\mathrm{Zn}$ concentrations in the rivers flowing through Beppu City, including the Haruki River, were very high and explained this phenomenon as a resulted of the discharge from hot springs. Statistical results did not show a relationship between $\mathrm{Zn}$ and the distance from the Haruki River in Beppu City, although the RDA results indicated a relationship with the Ono River. To summarize these results, the $\mathrm{Zn}$ source in Beppu Bay may be the discharge from hot springs in the western part of the bay, with the $\mathrm{Zn}$ concentrations in the surface sediments diluted with clastic sediments supplied from the Ono River containing little $\mathrm{Zn}$.

The PCA results showed that Ag also had the highest loading values in PC2, with trends similar to Mo, $\mathrm{Cd}$, and $\mathrm{Cu}$ (Figs. 4 and 5; Tables 3 and 4). However, these distribution patterns showed a small difference. The RDA results showed that the trend for Ag was in the middle point between the water depth and opposite 
trend in the distance from the Oita River (Fig. 6). M The simple correlation results showed that the Ag

concentration was related to these topographical parameters. These results suggested that both factors affected the spatial variation of the Ag concentration. In general, most of the Ag in the coastal sediments was from municipal and industrial waste water discharges (e.g., Flegal et al., 1995; Macdonald et al., 2008). In the same way, Ag was likely supplied from rivers flowing near industrial plants located in the southern coastal area of Beppu Bay.

In order to explain the sources of metals, it is necessary to discuss, not only river pathways, but also wind transport. In the case of Beppu Bay, eolian dust might contain crustics, volcaniclastic material distributed around Mt. Aso in the southwest of the bay and anthropogenic materials like $\mathrm{Pb}$, as described above. This study focused on surface sediment deposition processes and chemical behaviors of seawater. In addition, the supplied amount from wind transport is less than those from rivers in Beppu Bay. Therefore, it is difficult when considering bulk element concentrations to separate the supply from rivers and the atmosphere. A different approach such as one involving element isotopes could resolve this problem more comprehensively.

\subsection{Relationships with redox condition}

The RDA and simple correlation results revealed that the spatial variations in the $\mathrm{Mn}, \mathrm{Cu}, \mathrm{Mo}$, and $\mathrm{Cd}$ concentrations were closely related to the water depth (Fig. 6; Table 6). Kuwae et al. (2007) demonstrated 
that the water depth controlled the temperature and/or redox conditions of the seafloor, and that TOC, TN, TS,

and $\mathrm{C} / \mathrm{S}$ were sensitive to these variations in Beppu Bay. Thus, the spatial variations in these metal concentrations are probably related to the redox conditions. However, the RDA results showed non-significant relationships between these metal concentrations and the Eh values of the surface sediment and DO of the water at the bottom. It is highly possible that the causes for these results are related to measurement errors and differences in the time scales for the records of the sediment and water. The Eh values around the boundary area between the sediments and seawater varied rapidlly; therefore, it was difficult to standardize the measurements, and the measurement error was large. In addition, the DO and Eh values showed momentary records. When considering the sedimentation rates, which were calculated as $0.20-0.27$ $\mathrm{g} / \mathrm{cm}^{2} / \mathrm{yr}$ by Hoshika et al. (1988) for Beppu Bay, the parameters of the surface sediments in the uppermost 1 $\mathrm{cm}$ were averages for at least several years and reflected the variation in redox conditions for a longer time than the seasonal variations in the seawater. As a result, the RDA permutation test may not have registered dominant factors such as the DO and Eh. However, Shiozawa et al. (1977) clearly demonstrated that the water depth in Beppu Bay influences the vertical and seasonal variations in DO and Eh in the seawater; the long-term variation in the redox conditions may be closely related to the water depth rather than to DO and Eh.

The PCA results showed the same trends for the $\mathrm{Mo}, \mathrm{Cd}$, and $\mathrm{Cu}$ concentrations (Figs. 4 and 5) and the RDA results showed that these parameters and the water depth had similar trends (Fig. 6). These results 
a few years. The Mo and Cd concentrations in Beppu Bay were relatively high at the southwestern deep end with anoxic to euxinic conditions (Fig. 3). Thus, the Mo and $\mathrm{Cd}$ had high depositions under anoxic conditions in the deep parts of the bay. Our results were consistent with previous studies that focused on the metal concentrations in surface sediments, which revealed that Mo and $\mathrm{Cd}$ were abundant in suboxic to euxinic anoxic sediments (Emerson and Huested, 1991; Calvert and Pedersen, 1993).

Copper is essential for biological processes and shows a high affinity for humic substances, which represent a major component of organic matter in sediments (Calvert et al., 1985). The PCA results for the metals and organic geochemical properties showed that TOC, which indicates the deposition quantity of organic matter, had the same trend as $\mathrm{Cu}, \mathrm{Mo}$, and $\mathrm{Cd}$. Kuwae et al. (2007) suggested that high depositions of organic matter occurred in the deeper part of Beppu Bay under anoxic conditions. As a result, $\mathrm{Cu}$ accumulated with the organic matter and its concentration is indirectly controlled by the variation in the redox conditions.

The trend for $\mathrm{Mn}$ was the opposite to that for Mo and Cd, and the RDA results showed a negative correlation between the Mn concentrations and water depth. This suggested that oxic-anoxic and redox conditions also influenced the spatial variations in the Mn concentrations for the surface sediments of Beppu Bay. Manganese diffuses from sediments under anoxic conditions and is deposited by oxidation in oxic conditions (Calvert and Pederson, 1993). Hoshika et al. (1988) investigated the vertical variations in the Mn concentrations in two core sediments collected under anoxic conditions from the interior part of the bay and oxic 
than $2 \mathrm{~cm}$ below the surface in the bay mouth; they were observed to occur through post-depositional mobilization under reducing conditions in the deeper sediments before subsequent precipitation in the oxygenated surficial sediments. As a result, diagenetic behavior responded to redox conditions, which controlled the spatial variation of the Mn concentrations in Beppu Bay.

Table 8 shows the results of a comparison of the concentrations of $\mathrm{Mo}, \mathrm{Cd}, \mathrm{Cu}$, and $\mathrm{Mn}$, which were closely related with redox conditions, in 5 restricted sea areas along the coast. Manganese, $\mathrm{Cu}$, and Mo concentrations in Beppu Bay were in the same range as other areas. While, the Cd concentrations of Beppu Bay were much lower than those in other areas. Although our data could not indicate the reason for these results, perhaps differences in the water quality related elemental behavior or the amounts supplied from surrounding areas are contributing factors. To determine the exact cause, it will be necessary to compare the environmental characteristics of these areas in detail.

\section{Conclusion}

In this paper, we compared environmental parameters such as water depth, distances from river mouths, and measured data used in PCA and RDA to determine the supply sources of 14 metals in the surface sediments of Beppu Bay and elucidated the relationships between their concentrations and redox conditions. The 
in Beppu Bay were mainly controlled by two factors. One factor was the distance from the mouth of the Oita

River; this factor was significant for the $\mathrm{V}, \mathrm{Cr}, \mathrm{Co}$, and As concentrations. This relationship indicated that these metals were mainly supplied from the drainage area of the Oita River. The supply source for In is also the drainage areas of the Oita and Ono rivers, which empty into Beppu Bay. The $\mathrm{Mn}, \mathrm{Cu}, \mathrm{Mo}$, and $\mathrm{Cd}$ concentrations were closely related to the redox condition parameters, water depth, and the DO and Eh in the bottom water. The concentrations of these metals were controlled by the oxic-anoxic and redox conditions at the bottom. Molybdenum and Cd were found to accumulate in the deeper part under anoxic conditions; in contrast, the Mn concentration increased toward the bay mouth, which was oxic. Copper concentrations were found to increase in the anoxic areas, where organic matter such as humic substances may have been prevented from decomposing. Silver and $\mathrm{Pb}$ likely originated from anthropogenic discharges of industrial plants in the southern part of the bay and the burning of fossil fuels over the whole watershed area, respectively. The variations in the $\mathrm{Al}, \mathrm{Fe}$, and $\mathrm{Zn}$ concentrations were controlled by other factors not considered in this study and/or other multiple factors.

\section{Reference}

Adelson, J. M., Heltz, G. R., Miller, C. V., 2001. Reconstructing the rise of recent coastal anoxic; molybdenum in Chesapeake Bay sediments. Geochemica et Cosmochimica Acta 65, 
Birks, H. J. B., 1995. Quantitative paleoenvironmental reconstructions. in: Maddy, D., Brew,

J. S.(Eds.), Statistical Modelling of Quaternary Science Data. Technical Guide, 5. Quaternary Research Association, Cambridge, pp. 161-254.

Bowen, H. J. M., 1978. Environmental Chemistry of the Elements. Academic Press, London. ter Braak, C. F. J., 1988. CANOCO-a FORTRAN program for canonical community ordination by (oartial)(detrended)(canonical)correspondence analysis, principle components analysis and redundancy analysis (version 2.1). Technical Report LWA-88-02, GLW, Wageningen, pp 95.

ter Braak, C. F. J., Smilauer, P., 2002. CANOCO Reference Manual and Cano-Draw for Windows User's Guide: Software for Canonical Community Ordination (Version 4.5). Microcomputer Power, New York. Caccia, G. V., Millero J. F., Palanques, A., 2003. The distribution of trace metals in Florida Bay sediments. Marine Pollution Bulletin 46, $1420-1433$.

Caccia, G. V., Millero J. F., Palanques, A., 2003, The distribution of trace metals in Florida Bay sediments. Marine Pollution Bulletin 46, 1420-1433.

Calvert, S. E., Mukherjee, S., Morris, R. J., 1985. Trace metals in fulvic and humic acids from modern organic-rich sediments, Oceanologica acta 8, 167-173. 
sediments: implications for the geological record. Marine Geology 113, 67-88.

Emerson, S., Huested, S., 1991. Ocean anoxia and the concentrations of molybdenum and vanadium in seawater. Marine Chemistry 34, 177-196.

Ergin, M., Saydam, C., Baştürk, Ö., Erdem, E., Yörük, R., 1991. Heavy metal concentrations in surface sediments from the two coastal inlets (Golden Horn Estuary and İzmit Bay) of the northeastern Sea of Marmara. Chemical Geology 91, 269-285.

Flegal, A. R., Sanudo-Whilhelmy, S. A., Scelfo, G. M., 1995. Silver in the eastern Atlantic Ocean. Marine Chemistry 49(4), 315-320.

Francois, R., 1988. A study on the regulation of the concentrations of some trace metals (Rb, $\mathrm{Sr}, \mathrm{Zn}, \mathrm{Pb}, \mathrm{Cu}, \mathrm{V}, \mathrm{Cr}, \mathrm{Ni}, \mathrm{Mn}$ and $\mathrm{Mo}$ ) in Saanich Inlet sediments, British Columbia, Canada. Marine Geology 83, 285-308.

García, E. M., Cruz-Motta, J. J., Farina, O., Bastidas, C., 2008. Anthropogenic influences on heavy metals across marine habitats in the western coast of Venezuela. Continental Shelf Research 28, 2757-2766.

Hoshika, A., Shiozawa, T., Kitano, Y., 1988. Manganese, Iron, Copper, and Zinc in Sediment Cores from Seasonally Stratified Beppu Bay, the Seto Inland Sea, Japan., in: Wolf, D. A., O’Connor, T. P.(Eds), Oceanic Processes In Marine Pollution. Robert E. Krieger Publishing 
Hoshika, A., Takimura, O., Shiozawa, T., 1978. Vertical distribution of particulate manganese and iron in the Beppu Bay. Journal of the Oceanographical Society of Japan 34, 261-264.

Hyun, S., Lee, C. H., Lee, T., Choi, J. W., 2007. Anthropogenic contributions of heavy metal distributions in the surface sediments of Masan Bay, Korea. Marine Pollution Bulletin 54, 1031-1071.

Imai, N., Terashima, S., Katayama, H., Nakajima, T., Ikehara, K., Taniguchi, M., 1997. Geochemical behavior of heavy metal in coastal marine sediments from the eastern margin of the Japan Sea. Bulletin of Geological Survey of Japan 48, 511-529. (In Japanese with English abstract)

Imai, N., Terashima, S., Ohta, A., Mikoshiba, M., Okai, T., Tachibana, Y., Togashi, S., Matsuhisa, Y., Kanai, Y., Kamioka, H., 2004. Geochemical map of Japan. Geological Survey of Japan, Tsukuba. (in Japanese with English abstract)

Inouchi, Y., 1990. Origin of sand and its distribution pattern in the Seto Inland Sea, Southwest Japan. Bulletin of the Geological Survey of Japan 41, 49-86.

Kameda, T., Fujiwara, T., 1995. Ventilation time and anoxia of the benthic cold water in Beppu Bay. Bulletin of Coastal Oceanography 33, 59-68. (In Japanese with English abstract) 
Kuwae, M., Yamaguchi, H., Tsugeki,PKEIN., Miyasaka,PH., Fukumori, K., Ikehara, M.,

Genkai-Kato, M., Omori, K., Sugimoto, T., Ishida, S., Takeoka, H., 2007. Spatial distribution of organic and sulfur geochemical parameters of oxic to anoxic surface sediments in Beppu Bay in southwest Japan. Estuarin Coastal and Shelf Science 72, 348-358.

Lin, S., Hsieh, I. J., Huang, K. M., Wang, C. H., 2002. Influence of the Yangtze River and grain size on the spatial variation of heavy metals and organic carbon in the East China Sea continental shelf sediments. Chemical Geology 182, 377-394.

Macdonald, R. W., Johannessen, S. C., Gobeil, C., Wright, C., Burd, B., van Roodselaar, A., Pedersen, T. F., 2008. Sediment redox tracers in Strait of Georgia sediments - Can they inform us of the loadings of organic carbon from municipal wastewater?, Marine Environmental Research 66, S87-S100.

Neto, J. A. B., Gingele, F. X., Leipe, T., Brehme, I., 2006. Spatial distribution of heavy metals in surface sediments from Guanabara Bay: Rio de Janeiro, Brazil. Environmental Geology 49, $1051-1063$.

Ohta, A., Imai, N., Terashima S., Tachibana, Y., Ikehara, K., Okai, T., Ujiie-Mikoshiba, M., Kubota, R., 2007. Elemental distribution of coastal sea and stream sediments in the island-arc region of Japan and mass transfer processes from terrestrial to marine environments. Applied Geochemistry 22, 2872-2891. 
of useful metal elements from the spring to the river. Report of hot spring research in Oita Prefecture 58, 21-30. (In Japanese)

Pekey, H., 2006. The distribution and sources of heavy metals in Izmit Bay surface sediments affected by a polluted stream. Marine Pollution Bulletin 52, 1197-1208.

Reid, M. K., Spencer, K.L., 2009. Use of principal components analysis (PCA) on estuarine sediment datasets: The effect of data pre-treatment. Environmental Pollution 157, 2275-2281. Roskill Information Services Ltd., 1996. The Economic of Indium, 6th ed.

Rubio, B., Nombela, M. A., Vilas, F., 2002. Geochemistry of Major and Trace Elements in Sediments of Ria de Vigo (NW Spain): an Assessment of Metal Pollution, Marine Pollution Bulletin 40, 968-980.

Russe11, A. D., Morford, J. L., 2001. The behavior of redox-sensitive metals across a laminated-massive-laminated transition in Saanich Inlet, British Columbia. Marine Geology $174,341-354$.

Schropp, S. J., Lewis, F. G., Windom, H. L., Ryna, J. D., Calder, F. D., Burney, L. C., 1990. Interpretation of metal concentrations in estuarine sediments of Florida using aluminum as a reference element. Estuarines 22, 227-235.

Shiozawa, T., Kawana, K., Hoshika, A., Tanimura, T., Takimura, O., 1977. Vertical 
Oceanographical Society of Japan 33, 350-356. (in Japanese with English abstract)

Summers, J. K., Wade, T. L., Engle, V. D., Malaeb, Z. A., 1996. Normalization of metal concentrations in estuarine sediments from the Gulf of Mexico. Estuaries 19, 581-594. 
Table 1

Sampling location and organic geochemical properties of samples.

\begin{tabular}{|c|c|c|c|c|c|c|c|c|c|c|c|c|c|c|c|}
\hline \multirow{2}{*}{$\begin{array}{l}\text { Site } \\
\text { No. }\end{array}$} & \multirow{2}{*}{ Location } & \multirow{2}{*}{$\begin{array}{c}\text { Water } \\
\text { depth } \\
\text { (m) }\end{array}$} & \multicolumn{3}{|c|}{$\begin{array}{l}\text { The distance from } \\
\text { the river mouth }(\mathrm{km})\end{array}$} & \multicolumn{2}{|c|}{ Bottom water } & \multirow{2}{*}{$\begin{array}{l}\text { Eh in the } \\
\text { uppermost } \\
\text { surface } \\
\text { sediment } \\
(\mathrm{mV})\end{array}$} & \multicolumn{7}{|c|}{$\begin{array}{l}\text { Organic geochemical properties } \\
\text { (Kuwae et al., 2006) }\end{array}$} \\
\hline & & & Oita R. & Ono R. & Haruki R. & $\begin{array}{l}\text { Temp. } \\
\left({ }^{\circ} \mathrm{C}\right)\end{array}$ & $\begin{array}{c}\mathrm{DO} \\
(\mathrm{mg} / \mathrm{L})\end{array}$ & & $\begin{array}{l}\delta^{13} \mathrm{C} \\
(\%)\end{array}$ & $\begin{array}{l}\delta^{15} \mathrm{~N} \\
(\% 0)\end{array}$ & $\mathrm{C} / \mathrm{N}$ & $\begin{array}{l}\text { TOC } \\
(\%)\end{array}$ & $\begin{array}{l}\mathrm{TN} \\
(\%)\end{array}$ & $\begin{array}{l}\text { TS } \\
(\%)\end{array}$ & $\mathrm{C} / \mathrm{S}$ \\
\hline 1 & $3317.50 \mathrm{~N}, 13140.08 \mathrm{E}$ & 53.1 & 5.3 & 4.0 & 14.8 & 17.64 & ND & -156 & -22.7 & 5.4 & 9.6 & 2.6 & 0.28 & 0.68 & 3.8 \\
\hline 2 & $3317.38 \mathrm{~N}, 13137.99 \mathrm{E}$ & 55.9 & 3.7 & 6.7 & 11.9 & 13.54 & 0.21 & -53 & -22.5 & 5.3 & 9.5 & 2.6 & 0.28 & 0.76 & 3.4 \\
\hline 3 & $3316.45 \mathrm{~N}, 13137.34 \mathrm{E}$ & 50.7 & 1.7 & 7.5 & 11.2 & 17.82 & 0.81 & -160 & -24.7 & 3.6 & 11.3 & 2.5 & 0.22 & 0.62 & 4.0 \\
\hline 4 & $3316.20 \mathrm{~N}, 13135.98 \mathrm{E}$ & 56.8 & 2.6 & 9.5 & 9.5 & 15.45 & ND & -120 & -23.4 & 4.9 & 10.0 & 2.5 & 0.26 & 0.64 & 3.9 \\
\hline 5 & $3316.01 \mathrm{~N}, 13135.03$ & 59.9 & 3.9 & 11.2 & 8.2 & ND & 0.29 & -111 & -24.5 & 4.1 & 10.7 & 2.4 & 0.22 & 0.54 & 4.4 \\
\hline 6 & $3316.02 \mathrm{~N}, 13134.35 \mathrm{E}$ & 67.2 & 5.4 & 12.5 & 7.1 & 11.47 & 0.20 & -195 & -22.1 & 5.9 & 8.6 & 2.8 & 0.31 & 1.33 & 2.1 \\
\hline 7 & $3316.02 \mathrm{~N}, 13132.97 \mathrm{E}$ & 69.7 & 7.0 & 14.2 & 5.9 & 11.36 & 0.56 & -321 & -21.8 & 6.1 & 8.0 & 2.9 & 0.34 & 1.36 & 2.2 \\
\hline 8 & $3316.48 \mathrm{~N}, 13132.32 \mathrm{E}$ & 72.3 & 8.3 & 15.2 & 4.3 & 11.36 & 0.24 & -363 & -21.7 & 6.3 & 7.7 & 2.9 & 0.35 & 1.25 & 2.3 \\
\hline 9 & $3318.48 \mathrm{~N}, 13132.37 \mathrm{E}$ & 57.0 & 9.5 & 15.6 & 3.1 & 13.85 & 0.50 & -341 & -21.2 & 6.4 & 8.0 & 2.7 & 0.33 & 0.97 & 2.8 \\
\hline 10 & $3319.33 \mathrm{~N}, 13133.97 \mathrm{E}$ & 45.9 & 8.9 & 13.9 & 6.0 & ND & 0.90 & ND & -21.3 & 6.1 & 8.4 & 2.3 & 0.28 & 0.68 & 3.4 \\
\hline 11 & $3317.48 \mathrm{~N}, 13134.04 \mathrm{E}$ & 57.6 & 6.5 & 12.8 & 5.7 & 12.71 & 2.32 & -301 & -21.4 & 6.4 & 8.5 & 2.6 & 0.31 & 0.90 & 2.9 \\
\hline 12 & $3317.51 \mathrm{~N}, 13135.99 \mathrm{E}$ & 54.0 & 4.3 & 9.8 & 8.7 & 13.27 & 1.52 & -58 & -21.7 & 6.0 & 8.5 & 2.7 & 0.32 & 0.84 & 3.2 \\
\hline 13 & 33 19.32N, 131 36.07E & 34.8 & 7.4 & 11.2 & 8.8 & 25.13 & 1.40 & -100 & -21.5 & 6.1 & 8.2 & 2.2 & 0.28 & 0.70 & 3.2 \\
\hline 14 & $3319.33 \mathrm{~N}, 13138.03 \mathrm{E}$ & 44.6 & 7.1 & 8.7 & 11.9 & 19.96 & 3.23 & -264 & -21.5 & 6.1 & 8.4 & 2.4 & 0.29 & 0.68 & 3.6 \\
\hline 15 & $3319.33 \mathrm{~N}, 13139.97 \mathrm{E}$ & 39.0 & 8.0 & 6.7 & 14.9 & 20.58 & 4.15 & 90 & -21.8 & 5.7 & 8.2 & 2.3 & 0.29 & 0.66 & 3.5 \\
\hline 16 & $3320.35 \mathrm{~N}, 131$ 39.35E & 21.0 & 10.3 & 9.8 & 14.7 & 21.46 & 2.63 & 77 & -21.7 & 6.0 & 9.1 & 1.8 & 0.23 & 0.51 & 3.6 \\
\hline
\end{tabular}


Table 2

Summary of metal concentrations in surface sediment of Beppu Bay. The values of average crust were referred by Bowen (1978); sediments of Oita River by Imai et al., (2004)

\begin{tabular}{|c|c|c|c|c|c|c|c|c|c|c|c|c|c|c|}
\hline \multirow{2}{*}{ Site No. } & \multicolumn{14}{|c|}{ Concentrations of heavy metals ( $\mu \mathrm{g} / \mathrm{g}$ dry) } \\
\hline & Al & V & $\mathrm{Cr}$ & $\mathrm{Mn}$ & $\mathrm{Fe}$ & Co & $\mathrm{Cu}$ & $\mathrm{Zn}$ & As & Mo & $\mathrm{Ag}$ & $\mathrm{Cd}$ & $\ln$ & $\mathrm{Pb}$ \\
\hline 1 & 54000 & 78 & 41 & 571 & 33700 & 10.3 & 37.2 & 130 & 15.0 & 1.4 & 0.33 & 0.26 & 1.16 & 29.0 \\
\hline 2 & 61400 & 72 & 39 & 533 & 33400 & 9.6 & 34.6 & 133 & 12.1 & 1.4 & 0.35 & 0.27 & 1.14 & 29.3 \\
\hline 3 & 66400 & 87 & 54 & 574 & 39200 & 12.7 & 32.1 & 118 & 18.4 & 1.7 & 0.46 & 0.28 & 1.57 & 25.4 \\
\hline 4 & 44100 & 83 & 52 & 684 & 30900 & 12.3 & 34.7 & 123 & 16.7 & 3.1 & 0.43 & 0.33 & 0.11 & 26.5 \\
\hline 5 & 46100 & 95 & 76 & 924 & 36900 & 15.6 & 33.3 & 111 & 22.3 & 2.2 & 0.38 & 0.32 & 0.09 & 24.7 \\
\hline 6 & 56900 & 70 & 40 & 427 & 29100 & 9.0 & 35.8 & 136 & 10.9 & 10.4 & 0.41 & 0.41 & 0.10 & 28.7 \\
\hline 7 & 56500 & 66 & 36 & 382 & 27800 & 8.2 & 35.5 & 134 & 9.9 & 10.0 & 0.35 & 0.47 & 0.09 & 27.1 \\
\hline 8 & 64300 & 63 & 34 & 375 & 29100 & 7.7 & 35.9 & 133 & 8.6 & 12.9 & 0.38 & 0.46 & 0.08 & 28.2 \\
\hline 9 & 61300 & 62 & 38 & 460 & 29400 & 9.0 & 34.2 & 140 & 8.6 & 2.7 & 0.28 & 0.36 & 0.13 & 30.1 \\
\hline 10 & 68500 & 63 & 41 & 853 & 34700 & 9.4 & 30.8 & 129 & 7.2 & 1.6 & 0.22 & 0.19 & 0.09 & 29.2 \\
\hline 11 & 62500 & 70 & 44 & 511 & 35000 & 9.9 & 37.3 & 144 & 8.9 & 2.5 & 0.30 & 0.28 & 0.10 & 32.2 \\
\hline 12 & 70300 & 65 & 39 & 484 & 34600 & 9.1 & 34.6 & 142 & 11.5 & 2.7 & 0.30 & 0.29 & 0.13 & 27.0 \\
\hline 13 & 61300 & 63 & 40 & 1470 & 31500 & 9.2 & 28.6 & 120 & 7.9 & 1.7 & 0.24 & 0.19 & 0.10 & 28.8 \\
\hline 14 & 64400 & 64 & 42 & 2200 & 31400 & 9.4 & 31.3 & 127 & 8.8 & 1.3 & 0.24 & 0.26 & 0.15 & 29.0 \\
\hline 15 & 64500 & 65 & 44 & 1470 & 33400 & 9.7 & 31.8 & 126 & 9.5 & 1.1 & 0.24 & 0.24 & 0.11 & 31.0 \\
\hline 16 & 71800 & 66 & 40 & 902 & 30300 & 9.8 & 25.9 & 121 & 10.0 & 1.1 & 0.22 & 0.22 & 0.09 & 29.9 \\
\hline $\begin{array}{c}\text { average } \\
\text { crust }\end{array}$ & 82000 & 160 & 100 & 950 & 41000 & 20 & 50 & 75 & 1.5 & 1.5 & 0.07 & 0.11 & 0.05 & 14 \\
\hline $\begin{array}{c}\text { Sediments } \\
\text { of Oita R. }\end{array}$ & ND & 251 & 47 & ND & ND & 25 & 54 & 133 & 9 & 2 & ND & 0.17 & ND & 20.7 \\
\hline
\end{tabular}


Table 3

Results of PCA applied to 14 metals concentrations.

\begin{tabular}{ccccc}
\hline & PC1 & PC2 & PC3 & PC4 \\
\hline Eigenvalues & 0.43 & 0.28 & 0.12 & 0.07 \\
$\mathrm{Al}$ & -0.59 & -0.41 & 0.37 & -0.44 \\
$\mathrm{~V}$ & 0.98 & 0.11 & 0.06 & 0.08 \\
$\mathrm{Cr}$ & 0.90 & -0.17 & -0.20 & 0.20 \\
$\mathrm{Mn}$ & -0.08 & -0.73 & -0.41 & 0.08 \\
$\mathrm{Fe}$ & 0.63 & -0.41 & 0.52 & 0.04 \\
$\mathrm{Co}$ & 0.95 & -0.20 & -0.09 & 0.15 \\
$\mathrm{Cu}$ & 0.09 & 0.79 & 0.34 & 0.43 \\
$\mathrm{Zn}$ & -0.65 & 0.47 & 0.42 & 0.32 \\
$\mathrm{As}$ & 0.97 & 0.10 & 0.02 & -0.02 \\
$\mathrm{Mo}$ & -0.26 & 0.83 & -0.29 & -0.26 \\
$\mathrm{Ag}$ & 0.62 & 0.70 & 0.12 & -0.19 \\
$\mathrm{Cd}$ & -0.06 & 0.92 & -0.25 & -0.10 \\
$\mathrm{In}$ & 0.44 & -0.03 & 0.72 & -0.33 \\
$\mathrm{~Pb}$ & -0.73 & -0.25 & 0.24 & 0.42 \\
\hline
\end{tabular}


Table 4

Results of PCA applied to metals and organic geochemical properties.

\begin{tabular}{ccccc}
\hline & PC1 & PC2 & PC3 & PC4 \\
\hline Eigenvalues & 0.50 & 0.27 & 0.09 & 0.05 \\
$\mathrm{Al}$ & -0.45 & 0.33 & 0.62 & -0.41 \\
$\mathrm{~V}$ & 0.88 & -0.44 & -0.02 & 0.16 \\
$\mathrm{Cr}$ & 0.86 & -0.16 & -0.25 & 0.13 \\
$\mathrm{Mn}$ & 0.14 & 0.69 & -0.34 & -0.18 \\
$\mathrm{Fe}$ & 0.65 & 0.34 & 0.54 & -0.11 \\
$\mathrm{Co}$ & 0.94 & -0.14 & -0.15 & 0.17 \\
$\mathrm{Cu}$ & -0.23 & -0.76 & 0.29 & 0.43 \\
$\mathrm{Zn}$ & -0.78 & -0.20 & 0.40 & 0.35 \\
$\mathrm{As}$ & 0.88 & -0.44 & -0.04 & 0.09 \\
$\mathrm{Mo}$ & -0.53 & -0.70 & -0.26 & -0.29 \\
$\mathrm{Ag}$ & 0.36 & -0.88 & 0.11 & -0.10 \\
$\mathrm{Cd}$ & -0.38 & -0.85 & -0.25 & -0.10 \\
$\mathrm{In}$ & 0.47 & -0.17 & 0.72 & -0.15 \\
$\mathrm{~Pb}$ & -0.59 & 0.51 & 0.18 & 0.44 \\
$\delta^{13} \mathrm{C}$ & -0.89 & 0.44 & -0.04 & 0.10 \\
$\delta^{15} \mathrm{~N}$ & -0.92 & 0.30 & -0.12 & 0.16 \\
$\mathrm{C} / \mathrm{N}$ & 0.94 & -0.21 & 0.18 & 0.01 \\
$\mathrm{TOC}$ & -0.47 & -0.81 & 0.18 & -0.02 \\
$\mathrm{TN}$ & -0.74 & -0.63 & -0.06 & -0.13 \\
$\mathrm{TS}$ & -0.92 & -0.26 & 0.07 & 0.01 \\
$\mathrm{C} / \mathrm{S}$ & 0.90 & 0.34 & 0.04 & 0.11 \\
\hline & & & &
\end{tabular}


Table 5

The results of RDA for 14 metals and 7 environmental parameters.

\begin{tabular}{lcccc}
\hline & RD1 & RD2 & RD3 & RD4 \\
\hline Eigenvalues & 0.35 & 0.27 & 0.07 & 0.04 \\
geochemical data-environment correlations & 0.91 & 0.99 & 0.83 & 0.88 \\
Cumulative percentage variance of species data & 35.0 & 61.8 & 68.8 & 72.4 \\
$\begin{array}{l}\text { Cumulative percentage variance of geochemical } \\
\text { data-environment relation }\end{array}$ & 46.7 & 82.6 & 92 & 96.9 \\
\hline
\end{tabular}


Table 6

Inter-set correlations of the environmental variables with the axes $(A)$ and $t$ values of regression coefficients (B). Data are assumed to be statistically significant when the absolute t-values is higher than two (ter Braak and Smilauer, 2002)

\begin{tabular}{|c|c|c|c|c|}
\hline & $\mathrm{RD} 1$ & $\mathrm{RD} 2$ & RD3 & RD4 \\
\hline \multicolumn{5}{|l|}{ (A) Inter-set correlations } \\
\hline Water depth & 0.17 & 0.90 & -0.20 & -0.24 \\
\hline Bottom temperature & -0.28 & -0.29 & -0.04 & 0.56 \\
\hline Eh & 0.12 & -0.67 & 0.14 & 0.11 \\
\hline DO & -0.40 & -0.61 & 0.05 & -0.22 \\
\hline Oita R. & -0.79 & -0.18 & 0.22 & -0.03 \\
\hline Ono R. & -0.38 & 0.44 & 0.31 & -0.41 \\
\hline Haruki R. & 0.21 & -0.57 & -0.05 & 0.43 \\
\hline \multicolumn{5}{|c|}{ (B) t-values of regression coefficients } \\
\hline Water depth & -1.8 & 9.4 & -0.3 & 0.1 \\
\hline Bottom temperature & -2.4 & 4.6 & 0.0 & 2.4 \\
\hline Eh & -1.6 & 1.8 & -0.2 & 0.0 \\
\hline DO & -1.0 & -2.8 & -0.7 & -3.8 \\
\hline Oita R. & -3.7 & 0.5 & -2.1 & 1.2 \\
\hline Ono R. & 1.1 & 3.6 & 3.9 & 0.2 \\
\hline Haruki R. & 1.6 & 3.1 & 3.2 & 0.9 \\
\hline
\end{tabular}


Table 7 The results of simple correlation between metals concentrations and environmental parameters.

\begin{tabular}{|c|c|c|c|c|c|c|c|}
\hline & \multirow{2}{*}{$\begin{array}{l}\text { Water } \\
\text { depth }\end{array}$} & \multicolumn{3}{|c|}{$\begin{array}{l}\text { The distance from the } \\
\text { river mouth }\end{array}$} & \multicolumn{2}{|c|}{ Bottom water } & \multirow{2}{*}{$\begin{array}{l}\text { Eh in the } \\
\text { uppermost } \\
\text { surface } \\
\text { sediment }\end{array}$} \\
\hline & & Oita R. & Ono R. & Jaruki R. & Temp. & DO & \\
\hline $\mathrm{Al}$ & -0.46 & 0.48 & 0.06 & 0.10 & 0.23 & 0.43 & 0.17 \\
\hline $\mathrm{V}$ & 0.21 & $-0.77^{* *}$ & -0.38 & 0.21 & -0.06 & -0.32 & 0.15 \\
\hline $\mathrm{Cr}$ & 0.02 & $-0.53^{*}$ & -0.20 & 0.12 & 0.26 & -0.09 & 0.21 \\
\hline $\mathrm{Mn}$ & -0.60 * & 0.23 & -0.30 & 0.44 & $0.76^{* *}$ & $0.69^{* *}$ & 0.28 \\
\hline $\mathrm{Fe}$ & -0.17 & $-0.53^{*}$ & -0.45 & 0.28 & 0.22 & 0.07 & 0.32 \\
\hline Co & -0.05 & $-0.60^{*}$ & -0.32 & 0.23 & 0.29 & -0.09 & 0.28 \\
\hline $\mathrm{Cu}$ & $0.87 * *$ & -0.40 & 0.09 & -0.38 & $-0.81 * *$ & -0.42 & $-0.57^{*}$ \\
\hline $\mathrm{Zn}$ & 0.43 & 0.21 & 0.35 & -0.46 & $-0.76^{* *}$ & -0.08 & -0.45 \\
\hline As & 0.16 & $-0.75^{* *}$ & -0.42 & 0.27 & -0.02 & -0.30 & 0.23 \\
\hline Mo & 0.72 ** & 0.10 & $0.57^{*}$ & $-0.55^{*}$ & $-0.65^{*}$ & -0.49 & $-0.56^{*}$ \\
\hline $\mathrm{Ag}$ & 0.68 ** & $-0.76^{* *}$ & -0.03 & -0.19 & $-0.57^{*}$ & -0.65 & -0.30 \\
\hline $\mathrm{Cd}$ & $0.83^{* *}$ & -0.07 & $0.51^{*}$ & $-0.56^{*}$ & $-0.81^{* *}$ & $-0.51^{*}$ & $-0.67^{* *}$ \\
\hline $\ln$ & 0.01 & $-0.56^{*}$ & $-0.64^{* *}$ & 0.43 & 0.06 & -0.24 & 0.11 \\
\hline $\mathrm{Pb}$ & -0.32 & $0.63^{*}$ & 0.05 & 0.06 & 0.13 & 0.52 & 0.02 \\
\hline
\end{tabular}


Table 8

Results of comparing with concentrations of $\mathrm{Mn}, \mathrm{Cu}, \mathrm{Mo}$ and $\mathrm{Cd}$ in 5 restricted areas.

\begin{tabular}{|c|c|c|c|c|}
\hline Area (reference) & $\mathrm{Mn}$ & $\mathrm{Cu}$ & Mo & $\mathrm{Cd}$ \\
\hline Beppu Bay (This study) & $\begin{array}{l}375 \\
-2200\end{array}$ & 25. 9-37. 3 & 1. $1-12.9$ & 0. $19-0.47$ \\
\hline $\begin{array}{l}\text { Saanich Inlet } \\
(\text { Francois, 1988) }\end{array}$ & ND & $30-50$ & $0-80$ & ND \\
\hline (Russel and Morford, 2001) & $\begin{array}{l}1040 \\
-1640\end{array}$ & ND & 26. 7-53. 3 & $0.91-4.76$ \\
\hline $\begin{array}{l}\text { Chesapeake bay } \\
(\text { Adelson et al., 2001) }\end{array}$ & ND & 11. $6-40$ & $0.9-3.6$ & ND \\
\hline $\begin{array}{c}\text { Masan Bay } \\
\text { (Hyun et al., 2007) }\end{array}$ & ND & $\begin{array}{l}13.50 \\
-90.69\end{array}$ & $0.0-10.5$ & $0.10-7.47$ \\
\hline $\begin{array}{c}\text { Strait of Georgia } \\
\text { (Macdonald et al., 2008) }^{5}\end{array}$ & $\begin{array}{l}450 \\
-1500 \\
\end{array}$ & ND & $0.1-0.4$ & $1-5$ \\
\hline
\end{tabular}

1 ; Ranges of 55 surface sediment samples.

2; Ranges in $0-5.4 \mathrm{~cm}$ of one core.

; Ranges in $0-25 \mathrm{~cm}$ of three cores.

; Ranges in 56 surfase sediment samples.

5; Rages of the uppermost values of seven cores. 


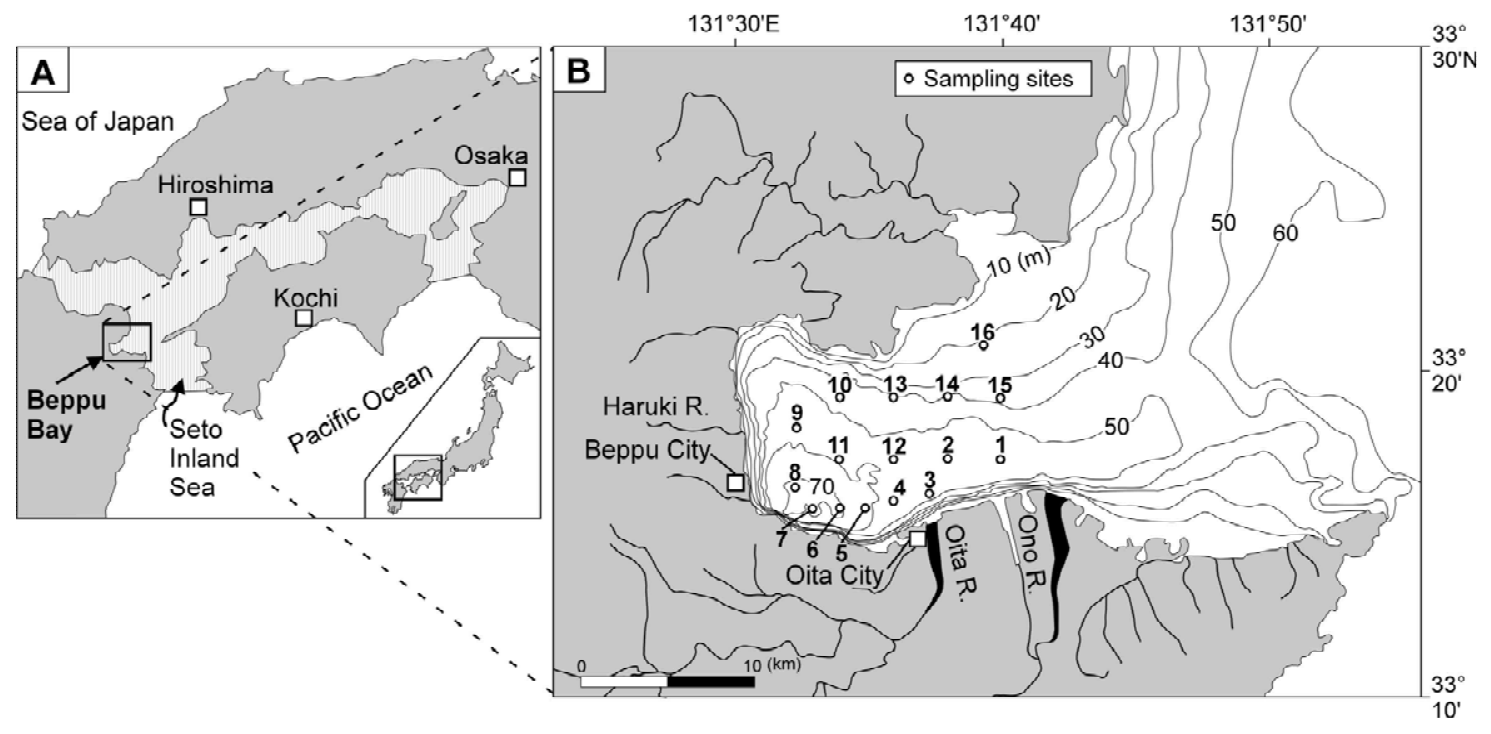

Fig. 1 Study area and sampling sites in Beppu bay, southwest Japan. Contour lines of water depth are an interval of $10 \mathrm{~m}$. 

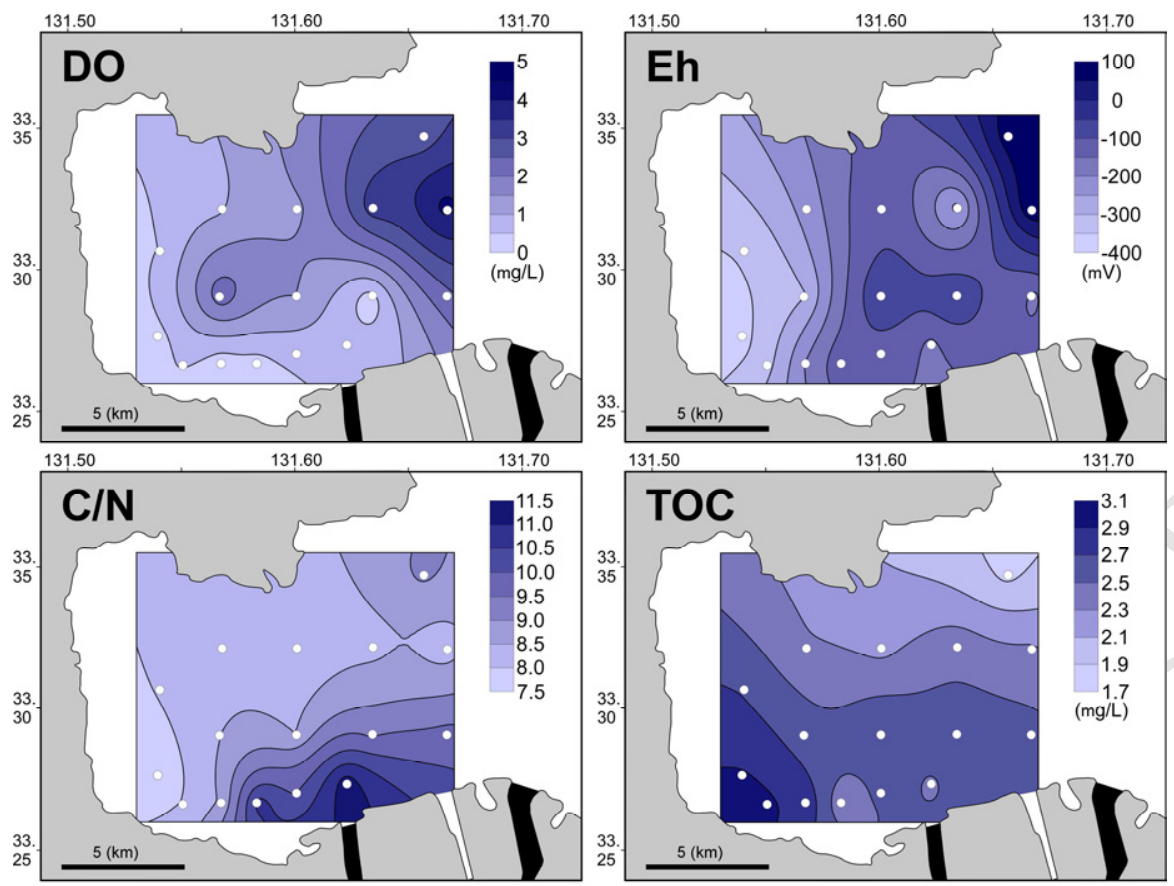

Fig. 2 Distribution map of mesured data and organic matter prameters. Open circles in the map show the sampling sites. DO denote the dissolved oxygen concentrations; Eh, the redox potential; $\mathrm{C} / \mathrm{N}$, the ratio of total organic carbon to total nitrogen; TOC, total organic carbon 

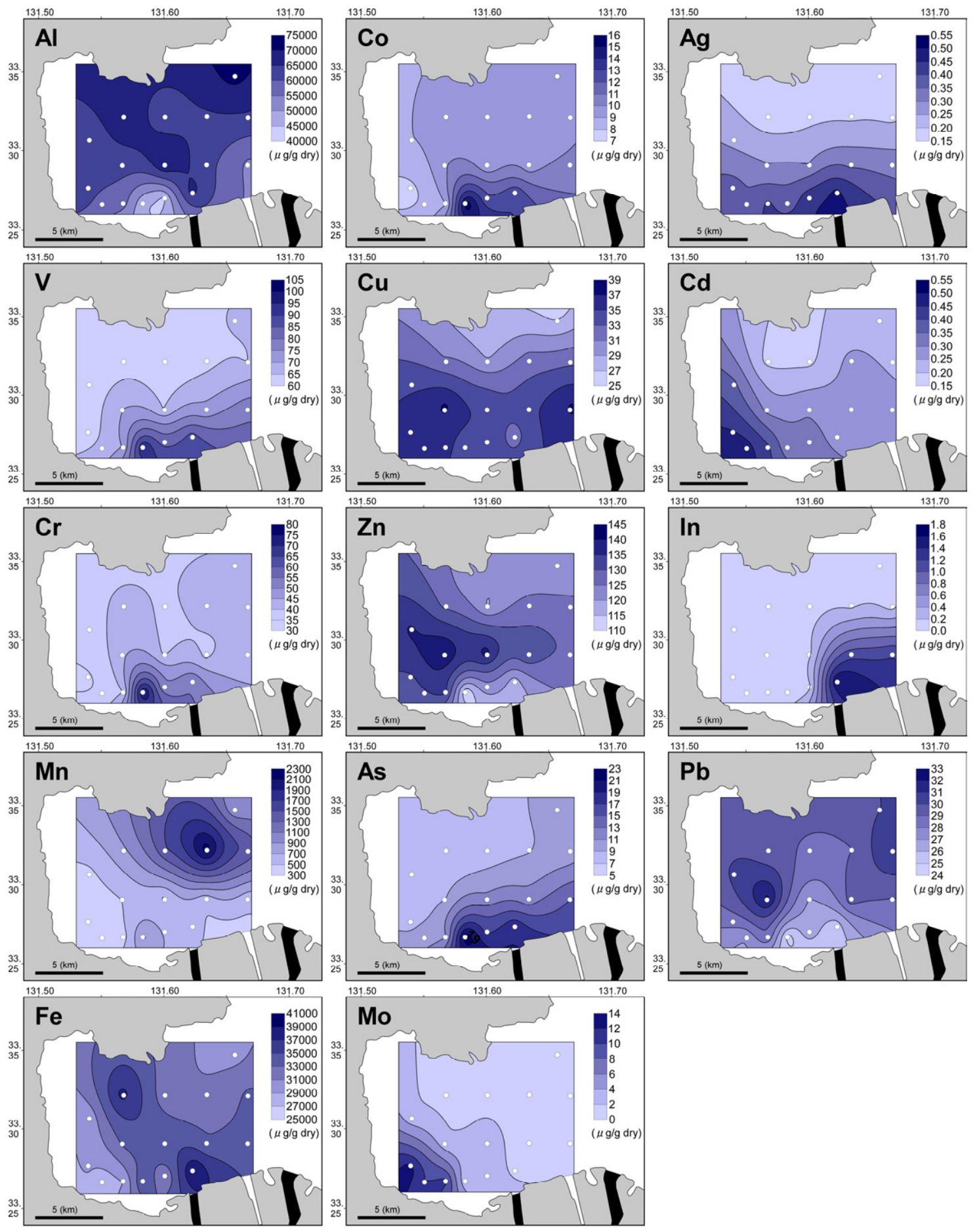

Fig. 3 Distribution maps of 14 metal concentrations. Open circles in the map show the sampling sites. 


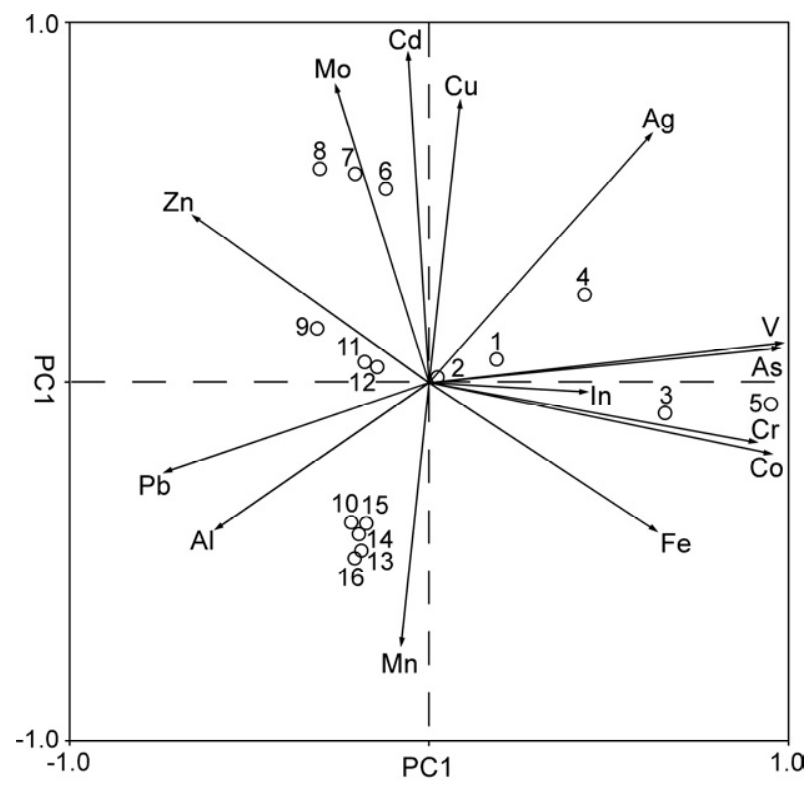

Fig. 4 Result of principal component analysis (PCA) of 14 metal parameters from surface sediments in Beppu Bay. 


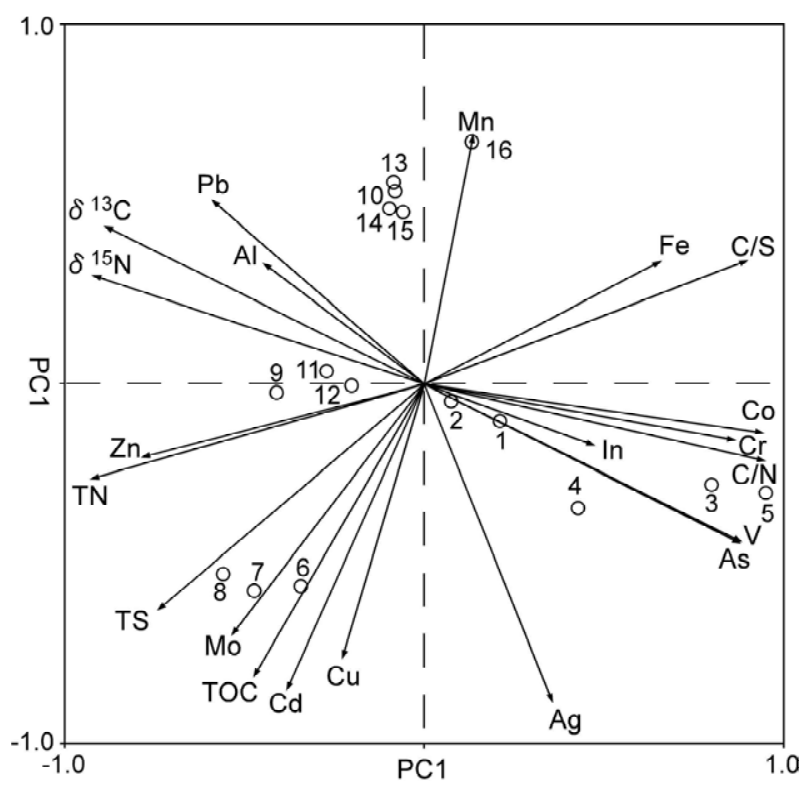

Fig. 5 Result of principal component analysis (PCA) of metal and organic matter parameters from surface sediments in Beppu Bay. 


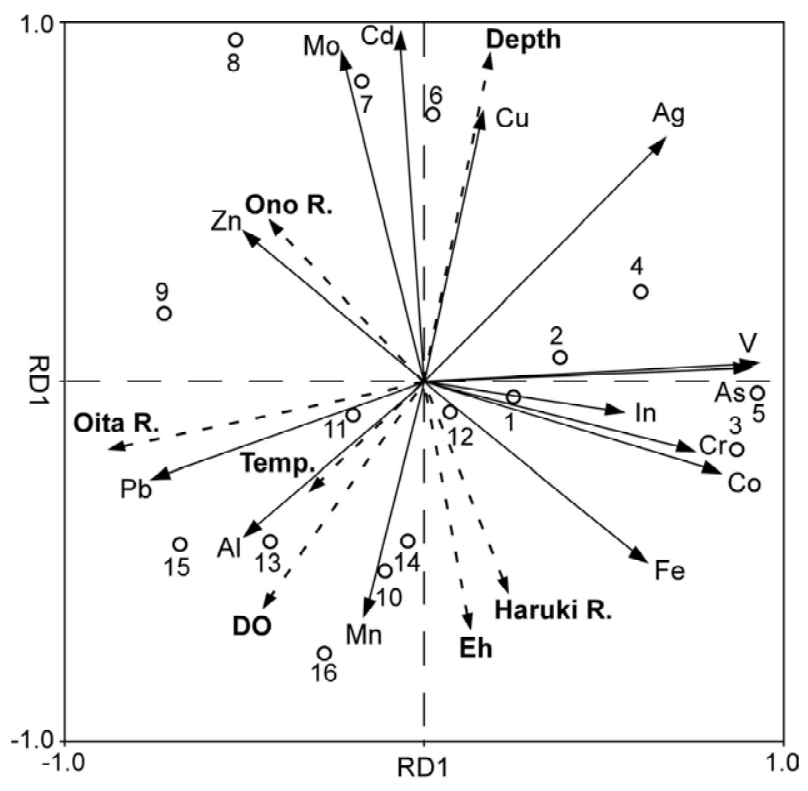

Fig. 6 Result of redundancy analysis (RDA) between metal concentrations and environmental parameters in Beppu Bay. Open circles with numbers denote RD scores of each site. Oita, Ono and Haruki R. denote the distances between the sampling site and the mouth of each river; depth; the water depth; Temp, the bottom temperature; DO, the dissolved oxygen concentrations; Eh, the redox potential. 